\title{
FAKTOR YANG MEMPENGARUHI RENDAHNYA HASIL BELAJAR MATEMATIKA SISWA MTS ISKANDAR MUDA BATAM
}

\author{
Ayu Ardilla, Suryo Hartanto* \\ Program Studi Pendidikan Matematika, Fakultas Keguruan dan Ilmu Pendidikan \\ Universitas Riau Kepulauan, Batam, Kepulauan Riau \\ Email: "suryo@fkip.unrika.ac.id
}

\begin{abstract}
Abstrak. Penelitian ini bertujuan untuk mengetahui dan mendeskripsikan faktor-faktor apa saja yang mempengaruhi rendahnya hasil belajar matematika siswa kelas VII A MTs Iskandar Muda Batam. Penelitian ini menggunakan metode kualitatif dengan teknik pengumpulan data observasi, wawancara, dokumentasi dan triangulasi. Sampel yang digunakan dalam penelitian ini yaitu snowball sampling. Instrument penelitian adalah peneliti sendiri dengan validitas data diperoleh dari data jenuh. Analisis data dengan Spradley dilakukan berurutan, melalui proses analisis domain, taksonomi, komponensial, dan tema budaya. Berdasarkan hasil penelitian terdapat 4 (empat) faktor yang mempengaruhi rendahnya hasil belajar siswa yaitu, kurangnya minat siswa terhadap pelajaran matematika, kurangnya konsentrasi siswa selama proses pembelajaran, rendahnya pemahaman konsep siswa, serta kurangnya kedisiplinan siswa.
\end{abstract}

Kata Kunci: Faktor internal, Faktor eksternal, hasil belajar

Abstract. This research aims to know and describe the factors that affect the low result in Mathematics subject at seventh grade students of MTs Iskandar Muda Batam. This research is qualitative metodh with observation, interview, documentation and triangulation. The sample used snowball sampling. The instrument research is the researcher with the validity of the data obtained from. Data analysis according to Spradley done through a process of sequential, domain analysis, taxonomy, componential, and cultural themes. Based on the research there are four factors that affect student learning outcomes are, the lack of interest of student towards Mathematics subject, the lack of concentration of students during the learning process, the lack of understanding the concept of student, as well as a lack of discipline.

Keyword: Internal factors, External factors, Learning outcomes

\section{Pendahuluan}

Berdasarkan observasi penelitian yang dilakukan peneliti selama menjalani Program Praktek Lapangan (PPL) pada bulan Agustus sampai Desember 2016 di sekolah MTs Iskandar Muda Batam, yang mana sebagian besar siswa khususnya kelas VII. A nilai hasil belajar matematikanya belum memenuhi Kriteria Ketuntasan Minimal (KKM) yang ditetapkan sekolah yaitu 70 untuk mata pelajaran matematika. Berikut data hasil belajar matematika siswa kelas VII. A dapat dilihat pada tabel 1di bawah ini: 
Tabel 1. Nilai Ulangan Harian Matematika Siswa MTs Iskandar Muda Batam

\begin{tabular}{lcccc}
\hline \multicolumn{1}{c}{ Materi } & KKM & Tuntas & Tidak Tuntas & Persentase Ketuntasan \\
\hline Bilangan Bulat & 70 & 4 & 15 & $21,05 \%$ \\
\hline Pecahan & 70 & 6 & 13 & $31,58 \%$ \\
\hline Himpunan & 70 & 5 & 14 & $26,32 \%$ \\
\hline Bentuk Aljabar & 70 & 4 & 14 & $22,22 \%$ \\
\hline
\end{tabular}

Sumber: Guru mata pelajaran matematika siswa kelas VII. A MTs Iskandar Muda

Berdasarkan pada tabel 1 di atas, persentase ketuntasan nilai hasil ulangan harian matematika siswa rata-rata masih di bawah $75 \%$. Pada ulangan harian materi bentuk aljabar terdapat satu siswa yang tidak hadir dikarenakan sedang sakit. Sehigga jumlah siswa dengan persentase ketuntasan berbeda dengan materi sebelumnya yang jumlah siswa hadir semua. Berdasarkan pada observasi lanjutan dan informasi yang diperoleh dari siswa beserta guru, diduga rendahnya hasil belajar matematika siswa ini disebabkan oleh banyak faktor yang mempengaruhinya.Dana Ratifi Suwardi (2012) terdapat 6 (enam) faktor yang mempengaruhi hasil belajar siswa yaitu (1) faktor psikologi siswa (27,54\%) yang terdiri dari kesulitan mengerjakan tugas, nilai pelajaran, bakat siswa, minat, kesiapan, dan motivasi, (2) faktor lingkungan masyarakat $(10,18 \%)$ yang terdiri dari teman bergaul, media, dan keaktifan siswa dalam organisasi, (3) faktor lingkungan sekolah $(8,70 \%)$ yang terdiri dari disiplin sekolah, relasi siswa dengan siswa, dan alat pengajaran, (4) faktor lingkungan keluarga $(6,50 \%)$ yang terdiri dari latar belakang keluarga dan pengertian orang tua, (6) faktor waktu sekolah $(6,23 \%)$.

Berdasarkan rendahnya capaian belajar siswa kelas VII. A MTs Iskandar Muda Batam dan observasi yang dilakukan peneliti, ketika proses pembelajaran berlangsung, banyak siswa tidak memperhatikan seperti melamun, mengantuk, dan mengobrol dengan temannya. Hal ini berdampak pada saat guru memberikan latihan soal siswa tidak dapat mengerjakan karena tidak memahami materi yang telah dijelaskan guru. Sehingga konsentrasi siswa dalam memperhatikan penjelasan guru berpengaruh juga terhadap pemahaman siswa. Konsentrasi belajar merupakan salah satu aspek psikologis yang seringkali tidak begitu mudah untuk diketahui oleh orang lain selain individu yang sedang belajar. Hal ini disebabkan kadangkadang apa yang terlihat melalui aktivitas seseorang belum tentu sejalan dengan apa yang sesungguhnya sedang individu tersebut pikirkan (Aunurrahman, 2014).

Pemahaman siswa terhadap materi matematika ini sangat penting bagi siswa dalam menyelesaikan soal-soal yang diberikan guru baik latihan, tugas, maupun ulangan. Dimana peneliti melihat ketika dijelaskan materi siswa mengatakan paham dan mengerti, namun ketika diberikan soal kelihatan siswa tidak dapat mengerjakannya dengan alasan lupa caranya, ribet, serta bingung. Selain itu ketika diberikan tugas, ada beberapa siswa tidak mengumpulkan, mengerjakan hanya sebagian karena membuatnya di kelas jadi tidak siap menyelesaikannya, ada yang beralasan buku PR ketinggalan di rumah, serta ada siswa yang sama sekali tidak tahu kalau ada PR yang diberikan oleh guru. 
Berdasarkan informasi yang didapat peneliti dari siswa kelas VII. A MTs Iskandar Muda batam, siswa mengatakan proses pembelajaran di sekolah hanya menggunakan buku LKS (Lembar Kerja Siswa) yang menjadi buku panduan siswa dalam belajar, siswa ketika belajar diberikan catatan oleh guru, dan guru juga meminta siswa untuk memfotocopi buku panduan guru namun siswa terkadang lupa atau tidak memiliki uang untuk memfotocopi buku tersebut. Siswa juga mengatakan selain menggunakan buku, guru matematika juga menggunakan media powerpoint atau video pembelajaran, dimana siswa menganggap penggunaan media tersebut terlalu cepat penjelasannya sehingga materi yang disampaikan kurang dimengerti dan kurang dipahami.

Sebagian besar siswa juga mengatakan tidak menyukai pelajaran matematika dengan alasan matematika dianggap pelajaran yang rumit, banyak rumus yang dihapal, serta penuh dengan angka-angka. Sehingga siswa kurang berminat terhadap pelajaran matematika mengakibatkan ketika guru menjelaskan materi sebagian siswa kurang aktif dan terlibat dalam proses pembelajaran. Selain itu mereka juga jarang mengulang materi yang telah diajarkan di rumah, karena lebih sering bermain bersama teman atau bermain handphone. Sehingga ketika diberikan tugas, sebagian siswa mengatakan sering lupa membuat tugas yang diberikan oleh guru karena keasyikan bermain bersama teman. Sebagian siswa juga menganggap orang tua di rumah kurang memperhatikan proses belajar di rumah seperti jarang bertanya tentang apakah ada tugas yang diberikan oleh guru dan jarang membimbing serta membantu dalam belajar.

Selanjutnya berdasarkan pada wawancara dengan guru matematika MTs Iskandar Muda Batam yang mengatakan bahwa di dalam proses pembelajaran sebagian siswa kelas VII masih dalam masa peralihan dari SD dimana siswa masih kurang aktif, kurang berkonsentrasi seperti ketika guru menjelaskan ada siswa yang mengobrol dengan teman sebelahnya, ada yang melamun, serta mengantuk ketika belajar, siswa juga cenderung pasif hanya menerima materi yang disampaikan oleh guru tanpa bertanya materi yang belum dipahami. Sehingga guru selalu memberikan catatan materi beserta contoh soal maupun latihan soal kepada siswa, hal ini dilakukan karena siswa hanya mempunyai referensi buku LKS saja dalam menunjang proses belajar mengajar. Maka setiap siswa wajib mencatat materi yang telah diberikan, karena catatan tersebut akan diberi nilai sebagai nilai tambahan serta berguna sebagai bahan ajar untuk dipelajari di sekolah maupun di rumah.

Guru matematika MTs Iskandar Muda Batam juga mengatakan selalu memberikan tugas setiap minggu kepada siswa dengan alasan tugas tersebut dapat meningkatkan pemahaman siswa serta menjadi alasan siswa untuk membuka buku di rumah dalam mengulang materi yang telah diajarkan di sekolah. Namun ketika diberikan tugas tersebut terdapat beberapa siswa yang tidak mengumpulkan tugas tersebut dengan alasan lupa, buku ketinggalan di rumah, serta ada siswa yang mengatakan semalam diajak orangtua jalan-jalan sehingga lupa membuat PR.

Dengan demikian guru menganggap orang tua siswa memiliki peranan yang penting dalam pendidikan siswa, karena pendidikan siswa tidak hanya diserahkan kepada sekolah saja namun orang tua juga harus terlibat dalam memperhatikan pendidikan siswa seperti orang tua dirumah bertanya kepada anak tentang tugas di sekolah, mengingatkan anak untuk belajar, serta membimbing dan membantu anak dalam belajar. Guru juga mengatakan kondisi jam 
pelajaran sekolah MTs Iskandar Muda sekarang sudah full day, dimana siswa hampir seharian penuh berada di lingkungan sekolah dimulai dari jam 07:30 sampai 16:00 wib. Apalagi ketika jam pelajaran matematika di jam siang, hal ini juga membuat siswa terkadang lelah, mengantuk, malas, dan bosan di dalam pembelajaran. Sehingga pelajaran yang diterima menjadi kurang optimal. Berdasarkan pemaparan masalah tersebut maka tujuan penelitian ini adalah untuk mengetahui dan mendeskripsikan faktor-faktor apa saja yang mempengaruhi rendahnya hasil belajar matematika siswa kelas VII. A MTs Iskandar Muda Batam.

\section{Metode Penelitian}

Penelitian ini menggunakan pendekatan kualitatif dengan mengkaji perspektif partisipan dengan strategi-strategi yang bersifat interaktif dan fleksibel, sehingga dengan menggunakan metode ini peneliti mendeskripsikan secara lebih teliti mengenai faktor-faktor apa saja yang mempengaruhi rendahnya hasil belajar matematika siswa kelas VII. A MTs Iskandar Muda Batam. Dengan demikian, penelitian kualitatif adalah penelitian yang digunakan untuk meneliti pada kondisi objek alamiah dimana peneliti merupakan instrument kunci. Sehingga dalam hal ini peneliti menggunakan metode studi kasus. Studi kasus (case study) ialah sebuah metode penelitian yang digunakan untuk memperoleh gambaran yang rinci mengenai aspekaspek psikologis seorang siswa atau sekelompok siswa tertentu.

Teknik sampling yang dipakai dalam penelitian ini adalah snowball sampling yakni peneliti membiarkan sampel bergulir seperti bola salju, sampai titik jenuh data artinya tidak ada lagi kemungkinan data yang dikumpulkan untuk mendukung sebuah penelitian. Dalam penelitian kualitatif, teknik pengumpulan data yang utama adalah observasi partisipan, wawancara mendalam, studi dokumentasi, dan gabungan ketiganya atau triangulasi. Dalam penelitian ini, peneliti menggunakan analisis model Spradley melalui proses analisis domain, taksonomi, komponensial, dan tema kultural dengan alasan bahwa analisisnya akan lebih lengkap dan tidak perlu diulang-ulang.

\section{Hasil Penelitian Dan Pembahasan}

Data penelitian didapatkan dengan menggunakan teknik interaktif dan noninteraktif. Data interaktif diperoleh dari wawancara dan pengamatan berperan serta, sedangkan noninteraktif meliputi pengamatan analisis isi dokumen dan arsip. Data diperoleh dari beberapa informan melalui snowball sampling dengan demikian data yang didapatkan lebih akurat. Data diperoleh langsung dari objek yang akan diteliti yaitu dari subjek penelitian serta para informan. Subjek penelitian merupakan siswa kelas VII. A MTs Iskandar Muda Batam yang melaksanakan pembelajaran matematika di sekolah tersebut. Informan dalam penelitian ini terdiri dari Kepala Sekolah dan guru di MTs Iskandar Muda Batam. Instrumen penelitian adalah peneliti itu sendiri yang mana dapat menganalisis data-data yang diperoleh dengan menggunakan teknik pengumpulan data seperti observasi (pengamatan), wawancara mendalam, studi dokumentasi dan gabungan ketiganya yaitu triangulasi yang dapat digunakan guna untuk memvalidasi atau memperkuat hasil dari temuan penelitian. 


\section{Temuan Umum}

1) Siswa Menganggap Pelajaran Matematika Sulit

Matematika merupakan salah satu cabang ilmu pengetahuan yang sangat berperan penting dalam perkembangan dunia. Pelajaran matematika merupakan salah satu pelajaran yang kurang disukai dan dianggap rumit oleh siswa. Pelajaran matematika kurang disukai dan dianggap rumit karena rendahnya penguasaan dan kemampuan siswa dalam menguasai konsep dasar Matematika. Berdasarkan hasil wawancara dengan siswa MTs Iskandar Muda Batam, 65 persen siswa tidak menyukai pelajaran matematika karena pelajaran matematika dianggap pelajaran yang sulit, rumit, dan banyak rumus yang dihapal serta pada materi perkalian dan pembagian.

2) Kurangnya Minat Siswa

Minat adalah suatu rasa ketertarikan seseorang terhadap suatu hal tanpa ada yang menyuruh. Minat sangat berpengaruh terhadap belajar, karena bila pelajaran tidak sesuai dengan minat siswa, siswa tidak akan belajar dengan sebaik-baiknya dalam (Slameto, 2010). Beberapa metode dilakukan peneilti untuk mendapatkan informasi antara lain wawancara, observasi , selama proses pembelajaran ditemukan kurang lebih 25 persen siswa kurang tertarik dan terlibat dalam pembelajaran. Pembelajaran hanya berpusat pada guru, Kurangnya keterlibatan siswa dalam belajar ini dilihat dari siswa hanya diam dan menerima apa yang dijelaskan oleh guru dimana siswa tidak aktif bertanya atau merespon selama proses pembelajaran. Ketika guru meminta siswa bertanya untuk materi yang belum dipahami, tidak ada siswa yang mengangkat tangan mereka untuk bertanya..

3) Kurangnya Konsentrasi Siswa

Konsentrasi belajar merupakan salah satu aspek psikologis yang seringkali tidak mudah untuk diketahui oleh orang lain selain diri individu yang sedang belajar. Hal ini disebabkan apa yang terlihat melalui aktivitas seseorang belum tentu sejalan dengan apa yang sedang seseorang pikirkan (Aunurrahman, 2014). Hal ini senada dengan observasi peneliti di kelas VII. A, ketika guru sedang menjelaskan materi beberapa siswa tidak memperhatikan seperti melamun, mengantuk, dan mengobrol dengan temannya. Selain itu siswa yang memperhatikan dengan serius, ketika guru memberikan pertanyaan atau latihan kepada siswa, siswa tersebut tidak bisa menjawab karena apa yang dijelaskan oleh guru tidak melekat pada otaknya. Hal ini kadang yang terlihat memperhatikan namun apa yang dipikirkan berbeda dengan yang dilihat.

4) Rendahnya Pemahaman Konsep Siswa

Pemahaman konsep adalah kemampuan siswa dalam menguasai suatu pelajaran. Berdasarkan observasi peneliti, dilihat siswa masih kurang dalam pemahaman konsep seperti untuk menghitung penjumlahan, pengurangan, perkalian, dan pembagian beberapa siswa masih belum bisa menyelesaikannya. Hal ini juga akan berpengaruh pada materimateri selanjutnya yang saling berkaitan satu sama lain.

Hasil wawancara dengan guru matematika MTS Iskandar Muda Batam, didapatkan informasi bahwa rendahnya pemahaman konsep siswa dipengaruhi oleh pemahaman konsep dasar matematika semenjak siswa tersebut berada di Sekolah Dasar. Pemahaman 
konsep dari Sekolah Dasar yang rendah akan mempegaruhi proses pembelajaran matematika di tingkat Sekolah menengah pertama.

5) Kurangnya Kedisiplinan Siswa

Kedisiplinan merupakan suatu bentuk ketaatan dan kepatuhan terhadap suatu aturan. Berdasarkan observasi peneliti, beberapa siswa kurang disiplin dalam mengumpulkan tugas PR yang di berikan oleh guru. Beberapa siswa seringkali tidak mengumpulkan, tidak membawa buku PR, dan terlambat dalam mengumpulkan tugas.

6) Padatnya Jam Pelajaran Sekolah

Pada dasarnya sekolah MTs Iskandar Muda sudah menerapkan system pembelajatan full day yaitu dari jam 07:30 sampai 16:00 wib siswa berada di lingkungan sekolah. Selama proses pembelajaran peneliti melihat siswa sering mengantuk, lelah, dan merasa malas. Apalagi pelajaran matematika jadwalnya di jam siang yaitu 13:00 WIB, beberapa siswa sudah terlihat kurang merespon pelajaran yang dijelaskan oleh guru.

7) Persepsi Siswa Terhadap Guru mengajar

Berdasarkan observasi, wawancara oleh peneliti di sekolah MTs Iskandar Muda Batam, siswa memiliki persepsi sendiri terhadap guru mengajar. Dimana siswa memilik rasa kesenangan sendiri terhadap cara mengajar guru. Dimana siswa kelas VII. A lebih menyukai guru menjelaskan materi secara konvensional dengan menggunakan papan tulis daripada melalui penggunaan media video pembelajaran. Siswa lebih merespon ketika guru menjelaskan secara langsung dibandingkan dengan menggunakan media siswa hanya diam dan menerima materi yang disampaikan melalui media tersebut. Siswa menganggap penjelasan guru yang menggunakan media video terlalu cepat, sehingga materi yang disampaikan tidak dapat dipahami dengan baik.

\section{Temuan Khusus}

Berdasarkan teknik analisis data digunakan untuk memproses pengolahan, pemisahan, mengelompokkan, dan memadukan sejumlah data yang dikumpulkan di lapangan secara empiris menjadi sebuah kumpulan informasi yang ilmiah, terstruktur, dan sistematis menjadi sebuah laporan hasil penelitian. Teknik analisis yang digunakan yaitu teknik analisis menurut Spredley.

\section{1) Analisis Domain}

Berdasarkan analisis domain dalam penelitian ini yang meneliti tentang faktor-faktor yang mempengaruhi rendahnya hasil belajar matematika siswa kelas VII. A MTs Iskandar Muda Batam, maka hasil yang dianalisis berupa faktor jasmaniah, faktor psikologi, dan faktor kelelahan.

Tabel 2. Analisis Domain

\begin{tabular}{|c|c|}
\hline DOMAIN & KATEGORI \\
\hline \multirow{3}{*}{$\begin{array}{l}\text { Faktor-faktor yang mempengaruhi rendahnya hasil } \\
\text { belajar matematika siswa kelas VII. A MTs } \\
\text { Iskandar Muda Batam }\end{array}$} & Faktor Jasmaniah \\
\hline & Faktor Psikologis \\
\hline & Faktor kelelahan \\
\hline
\end{tabular}




\section{2) Analisis Taksonomi}

Berdasarkan pada analisis domain dalam permasalahan yang terjadi di lapangan menunjukan bahwa faktor dominan yang mempengaruhi rendahnya hasil belajar matematika siswa kelas VII. A MTs Iskandar Muda Batam yaitu faktor psikologis.

\section{Tabel 3. Analisis Taksonomi}

\begin{tabular}{|c|c|}
\hline DOMAIN & SUB KATEGORI \\
\hline \multirow[t]{4}{*}{$\begin{array}{l}\text { Faktor } \\
\text { psikologis }\end{array}$} & $\begin{array}{l}\text { Siswa kurang berminat terhadap pelajaran Minat } \\
\text { matematika }\end{array}$ \\
\hline & $\begin{array}{l}\text { Kurangnya konsentrasi siswa selama proses Konsentrasi } \\
\text { pembelajaran }\end{array}$ \\
\hline & $\begin{array}{lllll}\begin{array}{l}\text { Kurangnya } \\
\text { dasar siswa }\end{array} & \text { pemahaman konsep matematika } & \begin{array}{l}\text { Pemahaman } \\
\text { konsep }\end{array} \\
\end{array}$ \\
\hline & $\begin{array}{l}\text { Kurangnya kedisiplinan siswa } \\
\text { mengumpulkan tugas }\end{array}$ \\
\hline
\end{tabular}

3) Analisis Komponensial

Dalam analisis komponensial yang dilakukan untuk mengetahui komponen makna domain yang digabungkan dengan kategori yang selanjutnya peneliti menemukan perbedaan diantara elemen-elemen dalam sebuah domain.

Tabel 4. Analisis Komponensial

\begin{tabular}{lll}
\hline \multicolumn{1}{c}{ DOMAIN } & \multicolumn{1}{c}{ KATEGORI } & SUB KATEGORI \\
\hline Faktor & $\begin{array}{l}\text { Siswa kurang berminat terhadap pelajaran } \\
\text { psikologis }\end{array}$ & $\begin{array}{l}\text { Menampilkan ciri- } \\
\text { ciri dan perbedaan }\end{array}$ \\
\cline { 2 - 3 } & $\begin{array}{l}\text { Kurangnya konsentrasi siswa selama proses } \\
\text { pembelajaran berlangsung }\end{array}$ & \\
& $\begin{array}{l}\text { Kusing-masing } \\
\text { dasar siswa }\end{array}$ & \\
& $\begin{array}{l}\text { Kurangnya kedisiplinan siswa dalam } \\
\text { mengumpulkan tugas }\end{array}$ & \\
& & \\
\hline
\end{tabular}

4) Analisis Tema Kultural

Kemudian pada tahap analisis tema kultural ini untuk menemukan tema budaya merupakan suatu langkah untuk memberikan suatu pandangan yang menyeluruh tentang suatu budaya. 
Tabel 5. Analisis Kultural

\begin{tabular}{|c|c|c|}
\hline TEMA BUDAYA & JENIS-JENIS TEMA & SUB KATEGORI \\
\hline $\begin{array}{l}\text { Faktor-faktor yang mempengaruhi } \\
\text { rendahnya hasil belajar matematika }\end{array}$ & $\begin{array}{l}\text { Faktor itu terjadi di dalam } \\
\text { proses pembelajaran }\end{array}$ & $\begin{array}{l}\text { Menampilkan tema } \\
\text { budaya pada domain }\end{array}$ \\
\hline siswa & $\begin{array}{l}\text { Faktor itu menyebabkan } \\
\text { rendahnya hasil belajar } \\
\text { matematika siswa }\end{array}$ & $\begin{array}{l}\text { yang umum } \\
\text { khusus }\end{array}$ \\
\hline
\end{tabular}

Berdasarkan temuan khusus setelah dilakukan analisis mengenai faktor-faktor yang mempengaruhi rendahnya hasil belajar matematika siswa kelas VII. A MTs Iskandar Muda Batam, yaitu:

a. Siswa kurang berminat terhadap pelajaran matematika

b. Siswa tidak berkonsentrasi selama pembelajaran

c. Rendahnya pemahaman konsep matematika dasar siswa

d. Kurangnya Kediplinan siswa

\section{Pembahasan}

Berdasarkan pada proses triangulasi dan analisis data menurut Spradley, fakta yang ditemukan peneliti yaitu di sekolah MTs Iskandar Muda, dimana dalam proses pembelajaran terdapat faktor yang mempengaruhi hasil belajar matematika siswa. Beberapa faktor yang dominan pada siswa kelas VII. A MTs Iskandar Muda Batam, yaitu:

\section{Siswa Kurang Berminat Terhadap Pelajaran Matematika}

Menurut Sutikno (2013), Minat adalah suatu rasa lebih suka dan rasa keterikatan pada suatu hal atau aktivitas tanpa ada yang menyuruh. Minat ini selalu diikuti dengan perasaan senang yang akhirnya memperoleh kepuasan.

Minat besar pengaruhnya terhadap belajar, karena jika bahan pelajaran yang dipelajari tidak sesuai dengan minat siswa, siswa tidak akan belajar dengan sebaik-baiknya. Bahan pelajaran yang menarik siswa, lebih mudah dipelajari dan disimpan (Slameto, 2010).

Berdasarkan hasil penelitian dengan beberapa metode yang digunakan baik guru atau siswa pada kelas VII. A MTs Iskandar Muda Batam, selama proses pembelajaran berlangsung siswa kurang terlibat dan tertarik di dalam pembelajaran. Hal ini dilihat siswa cenderung menerima dan hanya diam terhadap materi yang belum dipahami. Siswa cenderung malu atau takut untuk bertanya kepada guru. Selama proses pembelajaran terdapat siswa yang kurang merespon pada saat guru menjelaskan seperti tidak memperhatikan guru menjelaskan. Siswa kurang menanggapi penjelasan dari guru. Sehingga guru harus menggunakan berbagai metode dalam mengajar guna menarik perhatian siswa terhadap pelajaran matematika. Berdasarkan informasi yang didapat melalui guru matematika kelas VII. A yang mengatakan bahwa di dalam pembelajaran selalu menyesuaikan metode mengajar yang digunakan baik itu metode konvensional maupun penggunaan media powerpoint atau media video pembelajaran yang diharapkan dapat menunjang proses pembelajaran dalam meningkatkan ketertarikan siswa terhadap pelajaran matematika serta agar siswa tidak merasa bosan hanya satu metode saja yang digunakan dalam proses pembelajaran. Guru memiliki peranan penting dalam 
melaksanakan pembelajaran yang menarik untuk mencapai hasil belajar yang maksimal.(Hartanto, 2016). Menurut Aminah Ekawati, (2014), banyak faktor yang mempengaruhi hasil belajar baik yang datangnya dari dalam diri siswa. Motivasi merupakan suatu bentuk dorongan yang timbul pada diri seseorang, sedangkan minat merupakan kecendrungan untuk tetap memperhatikan pelajaran sampai berakhir disertai dengan rasa senang. Dimana hasil penelitian menunjukkan motivasi berpengaruh terhadap hasil belajar, minat berpengaruh terhadap hasil belajar, dan motivasi bersama-sama minat berpengaruh terhadap hasil belajar.

\section{Siswa Tidak Berkonsentrasi Selama Pembelajaran}

Di dalam proses pembelajaran selalu ditemukan faktor-faktor yang mempengaruhi proses belajar, salah satunya konsentrasi. Menurut Aunurrahman (2014), Konsentrasi merupakan salah satu aspek psikologis yang sering kali tidak begitu mudah untuk diektahui oleh orang lain selain individu yang sedang belajar. Hal ini disebabkan apa yang terlihat melalui aktivitas seseorang belum tentu sejalan dengan apa yan sesungguhnya sedang seseorang tersebut pikirkan.

Konsentrasi memiliki pengaruh yang besar terhadap belajar. Seseorang yang dapat belajar dengan baik adalah orang yang dapat berkonsentrasi dengan baik, dimana ia harus memiliki kebiasaan untuk memusatkan pikiran. Dalam kenyataannya seseorang sering mengalami kesulitan dalam berkonsentrasi, hal ini disebabkan karena kurangnya minat terhadap pelajaran yang dipelajari, terganggu oleh keadaan lingkungan (bising), pikiran yang kacau dengan masalah, bosan terhadap pelajaran dan lain-lain dalam Slameto (2010).

Hal ini berdasarkan fakta yang terjadi pada siswa kelas VII. A MTs Iskandar Muda Batam, ketika guru menjelaskan materi kepada siswa, sebagian siswa memperhatikan dengan serius dan beberapa siswa tidak memperhatikan guru menjelaskan seperti melamun, mengantuk, serta mengobrol dengan temannya. Hal ini akan berdampak pada kurangnya pemahaman siswa terhadap materi yang diajarkan oleh guru, karena siswa yang memperhatikan dengan serius belum sepenuhnya memahami materi yang telah diajarkan begitu juga sebaliknya siswa yang tidak memperhatikan materi yang didapat sangat kurang optimal.

Kesulitan berkonsentrasi merupakan indikator adanya masalah belajar yang dihadapi siswa, karena hal ini akan menjadi kendala di dalam mencapai hasil belajar yang diharapkan. Sehingga siswa hendaklah menyukai pelajaran yang dipelajari, mengesampingkan masalahmasalah ketika sedang belajar dengan memusatkan pikiran fokus pada pelajaran, serta bimbingan dari guru dalam memberikan perhatian serta bekal motivasi kepada siswa.

Berdasarkan hasil penelitian yang dilakukan oleh Ria Aviana \& Fitria Fatichatul Hidayah, (2015), bahwa terdapat pengaruh konsentrasi belajar siswa terhadap daya pemahaman materi, jika konsentrasi siswa rendah maka akan menimbulkan ketidakseriusan dalam belajar yang mana akan mempengaruhi daya pemahaman materi. Konsentrasi merupakan modal utama bagi siswa dalam menerima materi serta menjadi indikator suksesnya pelaksanaan pembelajaran. Faktor yang dapat membawa keberhasilan siswa dalam mencapai mencapai tujuan pembelajaran adalah konsentrasi yang baik. Dengan 
berkonsentrasi, maka segala hal dapat terekam baik-baik di dalam memori otak dan selanjut dengan mudah dapat dikeluarkan pada saat-saat dibutuhkan.

\section{Rendahnya Pemahaman Konsep Siswa}

Di dalam proses pembelajaran masalah yang terjadi dalam belajar memiliki kaitan satu sama lain, jika siswa tidak berkonsentrasi selama pembelajaran hal ini akan berdampak pada kurangnya pemahaman siswa. Rendahnya pemahaman konsep siswa yang dimaksud yaitu pemahaman siswa terhadap materi dasar matematika. Berdasarkan observasi peneliti di sekolah MTs Iskandar Muda Batam, di dalam proses pembelajaran ditemui beberapa siswa yang masih belum memahami materi dasar matematika seperti perkalian, pembagian serta cara menghitung bilangan berkoma. Sehingga ketika diadakan ulangan harian bilangan bulat yang berkaitan dengan perkalian, pembagian, pecahan, serta bilangan berkoma, nilai hasil ulangan matematika sebagian siswa kelas VII. A di bawah Kriteria Ketuntasan Minimal (KKM) yang ditetapkan sekolah yaitu 75\%. Kondisi ini mengidentifikasikan rendahnya pemahaman konsep materi dasar matematika siswa.

Hal senada dengan hasil wawancara bersama guru matematika MTs Iskandar Muda yang mengatakan bahwa kemampuan dasar yang dimiliki siswa masih kurang seperti perkalian, pembagian, serta menghitung bilangan berkoma siswa masih salah meletakan yang mana satuan, dimana yang harusnya dibelakang koma disejajarkan siswa masih belum paham. Sehingga hal ini mempengaruhi pemahaman berikutnya, jika kemampuan dasar yang dimiliki anak masih terlalu jauh dalam arti masih sangat kurang mengerti, dimana guru harus mengulang lagi, mengingatkan lagi kepada siswa, serta membuat siswa menjadi paham dulu baru bisa melanjutkan kemateri berikutnya.

Berdasarkan hasil penelitian yang dilakukan oleh Naingggolan, (2014) menyatakan bahwa terdapat faktor yang mempengaruhi rendahnya pemahaman konsep siswa antara lain: pembelajaran yang terlaksana cenderung berpusat pada guru, guru memberikan rumus-rumus dan memberi contoh soal serta penyelesaiannya. Kegiatan siswa hanya diseputar mengerjakan soal berdasarkan rumus yang ada dan berdasarkan contoh yang pernah diberikan oleh guru tanpa mengetahui dari mana datangnya rumus, Dengan pembelajaran yang berpusat pada guru, pemahaman terhadap konsep matematika tidak dapat berkembang. Oleh karena itu pemahaman konsep yang baik akan turut mempengaruhi daya berfikir siswa terhadap pemecahan masalah matematika.

Dengan demikian, diharapkan pembelajaran tidak hanya berpusat pada guru, namun siswa juga harus aktif dan terlibat langsung dalam membangun pemahaman terhadap materi yang dipelajari. Siswa tidak hanya menerima apa yang diberikan oleh guru, tetapi siswa harus berfikir dalam memecahkan permasalahan matematika.

\section{Kurangnya Kediplinan Siswa}

Selanjutanya ditemukan juga faktor dominan lainnya yaitu kedisiplinan siswa dalam tugas, di dalam proses pembelajaran guru memberikan tugas berupa PR kepada siswa dengan alasan ketika siswa diberikan tugas di rumah akan membuat siswa membuka buku pelajarannya serta dapat meningkatkan pemahaman siswa dalam mengulang materi yang telah diajarkan. Pada saat diberikan tugas tersebut, guru memberi waktu seminggu kepada siswa untuk mengerjakan tugas tersebut, tetapi ketika waktu yang telah ditetapkan untuk 
mengumpulkan tugas beberapa siswa ada yang tidak mengumpulkan. Dimana beberapa siswa beralasan lupa, tidak membawa buku PR, serta siswa mengatakan tidak tahu kalau ada PR yang diberikan oleh guru.

Berdasarkan informasi yang didapat dari guru matematika MTs Iskandar Muda yang mengatakan selalu memberikan tugas setiap selesai menjelaskan untuk melihat pemahaman siswa dan memberikan PR setiap selesai pembelajaran. Tugas tersebut diberikan waktu seminggu kepada siswa untuk mengerjakan, PR yang diberikan tidak banyak hanya sekitar 5 (lima) soal. Hal ini dilakukan agar siswa membuka buku dan belajar di rumah. Karena mungkin orang tua siswa di rumah hanya sekedar bertanya ada PR atau tidak, ketika siswa mengatakan tidak ada, siswa tidak akan belajar. Namun dengan PR ini diharapkan dapat meningkatkan kegiatan belajar siswa di rumah serta meningkatkan pemahaman siswa terhadap materi yang telah dipelajari. Selain itu diharapkan kepada orang tua tidak hanya menanyakan ada PR saja kepada anak, tetapi ikut membantu serta membimbing anak belajar.

Hal ini senada dengan hasil penelitian yang dilakukan oleh Resti Mulyati, dkk, (2013) yang menyatakan bahwa adanya pengaruh kedisiplinan siswa dan perhatian orangtua terhadap hasil belajar matematika yaitu $18,86 \%$. Kedisiplinan siswa merupakan faktor internal yang mempengaruhi hasil belajar matematika, sedangkan perhatian orang tua merupakan faktor eksternal. Keduanya harus saling mendukung untuk menyokong keberhasilan belajar siswa. Jika faktor internal dan eksternal sama-sama berpengaruh baik, maka akan semakin baik pula hasil belajar siswa. Semakin tinggi kedisiplinan dan perhatian orang tua, maka akan semakin tinggi juga hasil belajar siswa.

\section{Kesimpulan}

Berdasarkan penelitian dan pembahasan dapat disimpulkan bahwa hasil belajar matematika siswa kelas VII di MTs Iskandar Muda Batam rendah dipengaruhi oleh berbagai faktor internal maupun faktor eksternal. Berdasarkan hasil observasi dan wawancara dengan berbagai pihak serta dokumentasi terdapat 4 faktor yang mempengaruhi hasil belajar siswa MTs Iskandar Muda Batam yaitu kurangnya minat siswa terhadap pelajaran matematika, kurangnya konsentrasi siswa dalam memperhatikan guru yang sedang menjelaskan, kurangnya pemahaman konsep matematika dasar siswa, serta ketidaksiplinan siswa dalam mengumpulkan tugas yang diberikan oleh guru.

\section{DAFTAR PUSTAKA}

Aminah Ekawati, (2014). Pengaruh Motivasi dan Minat terhadap Hasil Belajar Matematika Kelas VII di SMPN 13 Banjarmasin. Lentera Jurnal Ilmiah Kependidikan. Vol. 9, No. 2, 1-10, Versi elektronik diakses dari http://ejurnal.stkipbjm.ac.id/. Pada tanggal 18 November 2016.

Aunurrahman, (2014). Belajar dan Pembelajaran $\left(9^{r d} e d\right)$. Bandung: Alfabeta.

Dana Ratify Suwardi, (2012). Faktor-faktor yang Mempengaruhi Hasil Belajar Siswa Kompetensi Dasar Ayat jurnal Penyesusaian Mata Pelajaran Akutansi Kelas XI IPS di SMA Negeri 1 Bae Kudus. Jurnal Pendidikan Ekonomi. Vol. 1, No.2, 1-7, Versi elektronik diakses dari http://journal.unnes.ac.id . Pada tanggal 18 November 2016. 
Hartanto, S. (2016). Pengaruh Penerapan Model Pembelajaran Talking Stick Terhadap Hasil Belajar Matematika Siswa Kelas Viii Smp Negeri 11 Batam, 5(April), 12-19. Retrieved from http://journal.unrika.ac.id/index.php/jurnalphythagoras/article/view/234/223

Nainggolan.S (2014). Penerapan Model Pencapaian Konsep Di SMP Negeri 1 Bilang Barat Untuk Peningkatan Kemampuan Pemahaman Konsep Siswa. Jurnal Suluh Pendidikan. Vol. 1, No. 1, 18-26, Versi Elektronik diakses dari http://akademik.uhn.ac.id/._Pada tanggal 9 Desember 2016.

Resti Mulyati, (2017). Pengaruh Kediplinan Siswa dan Perhatian Orang Tua Terhadap Hasil Belajar Matematika Siswa Kelas IV SD Se Kecamatan Ajibarang Tahun Ajaran 2013/2014. Vol 5. No. 3, Versi elektronik diakses dari http://jurnal.fkip.uns.ac.id. Pada tanggal 11 Februari 2017.

Ria Aviana \& Fitria Fatichatul Hidayah, (2015). Pengaruh Konsentrasi Belajar SiswaTerhadap Daya Pemahaman Materi Pada Pembelajaran Kimia. Jurnal Pendidikan Sains. Vol. 03, No. 01. Versi elektronik diakses dari http://jurnal.unimus.ac.id. Pada tanggal 11 Februari 2017.

Slameto, (2010). Belajar dan Faktor-faktor yang Mempengaruhinya (Rev. ed). Jakarta: Rineka Cipta.

Sutikno, S. (2013). Belajar dan Pembelajaran " Upaya Kreatif dalam Mewujudka Pembelajaran yang Berhasil” (Rev. ed). Lombok: Holistica. 